\title{
Lung infections in cardiac transplant recipients
}

\author{
Brînduşa Țilea ${ }^{1,2^{*}}$, Carmen Lucia Chiriac ${ }^{1,2}$, Anca Meda Georgescu²,2, Nina Șincu ${ }^{1,2}$, Mihaela Ispas ${ }^{3}$, Ioan Țilea ${ }^{2,4}$ \\ From The 9th Edition of the Scientific Days of the National Institute for Infectious Diseases Prof Dr Matei Bals \\ Bucharest, Romania. 23-25 October 2013
}

\section{Background}

Lung infections represent the most common cause of mortality and morbidity in heart transplant recipients. The most important factors which determine the prevalence and type of infection in this category of patients are those related to type, regimen and length of immunosuppressive treatment.

The objectives of this study involve the assessment of the prevalence of pulmonary infections and the impact of the antibacterial, antiviral prophylactic treatment on the onset of different lung infections, following heart transplantation.

\section{Methods}

Over the course of 48 months, we monitored 37 consecutive patients with cardiac transplant. Immunosuppressive therapy (cyclosporine, tacrolimus and prednisone) was administered. Post-transplant pulmonary infections were monitored. The etiological diagnosis (bacterial, viral, fungal and parasitic) was determined through the following methods: bacteriology, serum serology, sputum samples, bronchial biopsy, chest X-ray or chest CT scan respectively.

\section{Results}

The mean age was 39 (range: 12 to 59 years). There were 28 male (75.7\%) and 9 female (24.3\%) patients. During the first 6 months following the transplant, 12 patients developed viral pneumonia, 6 bacterial pneumonia, 3 pulmonary aspergillosis, 2 pulmonary tuberculosis. During the study, a total of 58 cases of respiratory infections were recorded, with a rate of 1.5 episodes per patient.

\section{Conclusion}

Different Gram positive and Gram negative bacterial infections, mainly community acquired, did not result in

\footnotetext{
* Correspondence: brindusa_tilea@yahoo.com

${ }^{1}$ Infectious Disease Clinic I, Tîrgu Mureş County Clinic Hospital, Romania
}

Full list of author information is available at the end of the article severe complications compared to fungal and specific infections which had a lethal outcome.

\section{Authors' details}

${ }^{1}$ Infectious Disease Clinic I, Tîrgu Mureş County Clinic Hospital, Romania. ${ }^{2}$ University of Medicine and Pharmacy, Tîrgu Mureş, Romania. ${ }^{3}$ Cardiology Clinic 2, Institute of Cardiovascular Diseases and Transplantation Tîrgu Mureş, Romania. ${ }^{4}$ Cardiac Rehabilitation Clinic, Tîrgu Mureş Emergency County Clinic Hospital, Romania.

Published: 16 December 2013

doi:10.1186/1471-2334-13-S1-026

Cite this article as: Tilea et al:: Lung infections in cardiac transplant recipients. BMC Infectious Diseases 2013 13(Suppl 1):O26.
Submit your next manuscript to BioMed Central and take full advantage of:

- Convenient online submission

- Thorough peer review

- No space constraints or color figure charges

- Immediate publication on acceptance

- Inclusion in PubMed, CAS, Scopus and Google Scholar

- Research which is freely available for redistribution

Submit your manuscript at www.biomedcentral.com/submit

\section{() Biomed Central}

C 2013 Țilea et al; licensee BioMed Central Ltd. This is an Open Access article distributed under the terms of the Creative Commons Attribution License (http://creativecommons.org/licenses/by/2.0), which permits unrestricted use, distribution, and reproduction in any medium, provided the original work is properly cited. 